\title{
Pests of rice agrobiocenosis type of structure
}

\author{
$N G$ Otamirzaev ${ }^{1, *}$ and $R$ Ibodullaeva ${ }^{2}$ \\ ${ }^{1}$ Tashkent State Agrarian University, University str., 2, Tashkent province, Uzbekistan, 100140 \\ ${ }^{2}$ Rice Scientific Research Institute, Tashkent, Uzbekistan
}

\begin{abstract}
The article identified 10 species of pests that damage rice plants during the season in rice agrobiocenosis. Leptestheria dahalacensis Sars, Apus concriformis Sh., Ostrinia nubilalis $\mathrm{Hb}$, and Cephus pygmaeus have been reported to cause damage to rice grasses. A growth calendar has been developed. In the pest experiment during the rice germination period, Nurell D was found to contain 55\% em.k. (Cypermethrin + chlorpriphos) in the variant applied to $1.51 /$ ha, the biological effectiveness of the drug is the highest for 14 days $-93.9 \%$, in the variant treated with Tayshin 500 s.d.g (Clothianidin) $-0.06 \mathrm{~kg} / \mathrm{ha}$ for 14 days $-93.3 \%$. In the experiment, the main pest Nurell $\mathrm{D}$ in the variant using $55 \%(1.5 \mathrm{l} / \mathrm{ha})$ was 73.8 quintals of Iskandar variety, ie 13.2 quintals per hectare compared to the control, the new chemical Taishin 500 s.d.g. $(0.06 \mathrm{~kg} / \mathrm{ha})$ yielded $70.7 \mathrm{q} / \mathrm{ha}$ in the variant in which the chemical agent was used, and 10.1 additional yields were reported.
\end{abstract}

\section{Introduction}

Rice is one of the oldest crops in the world and a staple food for a third of the world's population. 155 million worldwide in 2018. 765.6 million hectares of rice were planted. tons of rice were grown. In our country, rice is planted on 115,000 hectares, and the gross harvest is 450,000 tons $[1,2]$. This amount is enough to meet the growing demand of the country's population for rice, one of the main food products. According to official data, about 35,000 tons of rice products have been imported in recent years to fully meet the needs of the population. Therefore, in order to reduce rice imports and increase rice yields and meet the population's demand for rice and rice products, it is important to accelerate rice cultivation using modern methods, including research to protect rice from various pests $[2,4]$. As a result of the ongoing reforms in agriculture in our country, comprehensive measures are being taken to increase grain production, in particular, rice and rice production. In particular, the Decree of the President of the Republic of Uzbekistan dated January 16, 2018 "On measures to further ensure food security of the country" PD 5303, the Cabinet of Ministers of the Republic of Uzbekistan dated March 29, 2019 No. 259 "Rational placement of agricultural crops for 2019 harvest and on the forecast volumes of production" and No. 12 of December 12, 2019 "On additional measures for the development of rice" and set a number of tasks [3-5].

\footnotetext{
${ }^{*}$ Corresponding author: n.g.otamirzaev@yandex.com
} 
In order to further develop rice in our country, it is necessary to clarify the species composition of arthropods living in the rice ecosystem, identify dominant species, study the dynamics of their development, the degree of pest damage and economic damage, and create a coordinated protection system against these pests. remains relevant $[5,6]$.

In the developmental stages of rice, it is necessary to study the activities of pests in newly created varieties, to determine the level of damage, to improve methods of combating them [6].

At that time, rice was mechanized, the effects of pests in the germination phase were insignificant, and the chemicals recommended for pest control in the germination phase of rice were out of production due to their negative impact on the environment and their obsolescence [7-9].

At present, due to the creation of new high-yielding varieties of rice, late ripening and pre-flooding of rice, the seeds are shielded from pests in the germination and other phases of shrimp Apus concriformis Sh. favorable conditions are being created for the increase of [9-11].

In the world, pesticides are commonly used in the cultivation of agricultural crops to control pests and diseases and to ensure high yields. However, the accumulation of these chemical sources in crop fields increases the risk for biodiversity and human health [13].

Mankind is increasingly in need of food products that have little or no pesticide residue and are produced in a sustainable manner. Rice (Oryza sativa L) is a staple food for more than half of the world's population, but a significant loss of harvest each year is caused by insects and diseases [7, 12]. In 2012, rice was planted on more than 158 million hectares worldwide and harvested more than 465 million tons. Bangladesh alone planted 11.6 million hectares of rice in 2012 to produce 34 million tonnes of rice. Rice is Bangladesh's leading food product and occupies 75 percent of the cultivated area. It provides 75 percent of the calories and 55 percent of the protein needed in Bangladesh's average daily diet. The average farm size for households in Bangladesh, mainly small and remote farmers, is 0.53 hectares [14]. The increase in rice production is a pressing demand due to the rapid population growth in the world (including Bangladesh), seems impossible to achieve. Predicting climate change is a major challenge, along with managing a variety of pests that damage rice-planted areas [8].

Recent scientific studies have shown that insecticides have strong collateral effects on humans as well as pests [14-17]. For example, pest control only affects the environment, biodiversity, and human health.

The high incidence of pest-related incidents in recent years has been acknowledged by many scientists to be probably due to changes in climate and cropping systems in modern rice cultivation [18]. The fact that the main goal is to cultivate only high rice yields is often associated with overuse of fertilizers and pesticides, which in turn leads to a decrease in biodiversity and natural biological control. As a result, drinking water in rivers is highly polluted with pesticides and agricultural products are poisoned. Rapid and high levels of insecticide resistance of some pests can lead to many negative environmental consequences, such as an epidemic of secondary pests, environmental pollution and disturbance of the ecological balance [19]. These serious adverse effects damage the ecosystem, often leading to pest epiphytosis and in turn increasing pesticide consumption, resulting in the formation of circles. Excessive use of pesticides is a major barrier to sustainable agriculture in China and poses a threat to food security and human health [1520].

The main purpose of the research is to clarify the species composition of arthropods living in the rice ecosystem, to study the dynamics of their development, the degree of pest damage to rice and the criteria for economic damage, and to improve the means and methods to protect against pests during storage and processing. 


\section{Materials and methods}

The research was conducted on the experimental fields of the Rice Research Institute on 12 cards 2 edge. The institute is located in the south-eastern part of Tashkent region, in the Chirchik oasis, $15 \mathrm{~km}$ from Tashkent, on the left bank of the Chirchik River. Geographically, the coordinates of the institute are bounded on the Greenwich scale by 69018 'east longitude and $41020 \mathrm{~g}$ north latitude $[1,4]$.

Tashkent region is located in the eastern part of Uzbekistan and covers an area of 15.6 thousand $\mathrm{km}^{2}$, or $10 \%$ of the country's territory. It is bordered by the Republic of Tajikistan to the south, Kazakhstan to the northwest, Kyrgyzstan to the northeast, Namangan Province to the east, and Syrdarya Province to the southwest [1].

The natural climate of Tashkent region is sharply continental and arid, rich in heat and sunlight throughout the year. Sunny days average 295-390 hours during the summer months. This allows you to easily plant and harvest rice. Summers in Tashkent region are hot and dry. July is the hottest month. The growth and development of agricultural crops certainly depends on air temperature. The annual rainfall is $432-377 \mathrm{~mm}$. The highest rainfall is in the spring, ie in March [1, 2, 5].

In order to study the impact of weather on the growth and spread of the main rice pests in Tashkent region, the data of the meteorological station "Tuyabogiz" was used. . The relative humidity was observed to be around $45-76 \%$ on average during these months [39].

The soil of the experimental area is non-saline, moderate (RN-7.24), meadow-swamp soils. The amount of physical sludge in the driving layer is $40-60 \%$. Humus in the driving layer $(0-30 \mathrm{~cm})$ in the experimental field is $1.97 \%$, mobile nitrogen $23.5 \mathrm{mg} / \mathrm{kg}$, mobile phosphorus $109 \mathrm{mg} / \mathrm{kg}$, mobile potassium $27.5 \mathrm{mg} / \mathrm{kg}$.

There are no mineral salts due to the partial slope of the test site, the fact that the bottom layer of the soil consists of sand and pebbles, and the groundwater flows from the northeast to the southwest. Groundwater varies at a depth of 0.5-1.0 meters during periods when rice paddies are flooded. When the rice fields are not filled with water, the groundwater begins to deepen, which lasts until January at a depth of 1.5-1.6 m.

The number of pests, as well as agrotoxicological studies A.I. Kasyanov [1, 2], Sh.T. Khojaev [4], A.A. Shokirov [5], were studied based on the methods. The research was conducted on the experimental farms of the Rice Research Institute.

Samples were collected from the experimental fields to study the species composition of the insects and their distribution area. The types of samples obtained were stored in fixators prepared from a mixture of $5 \%$ formalin or $70 \%$ alcohol and $4 \%$ glycerin until determined using systematic experts. To determine the presence of pests, rice was examined in two phenological terms; the extent to which the crop was infested by pests of the crop - rice longhorn, crustaceans, rice flies, barley minnows, shore mosquito larvae - was determined. In this case, the observations were made on a sample area with 8 frames (frame lysimeter) measuring $25 \times 25 \times 30 \mathrm{~cm}$ per hectare.

At the end of the rice ginning and during the ginning period, re-monitoring was carried out by separating the sample plots in the same areas. The stalks were separated from the rice stalks by areas affected by the corn moth, and it was determined how many larvae were present in them.

A logarithmic scale was used to determine the number (density) of the pest in a bush and the population density in the rice field. Their density was determined using the following equation (1):

$$
\mathrm{S}=(\mathrm{LC}) / \mathrm{T}
$$


Where, S - number of pests; L - degree of damage to crops (in points); C - number of plants affected at this point; and, the number of plants in the T-sample.

In the study of the biological efficacy of pesticides in rice, the calculation of insects in small, field and production experiments, before and after processing held on days 1-3-7 and 14. The effectiveness of chemical and biological agents was calculated using the Abbot equation (2):

$$
\mathrm{BC}=\left(\mathrm{A}_{\mathrm{v}}-\mathrm{V}_{\mathrm{a}}\right) \times 100 / \mathrm{A}_{\mathrm{v}}
$$

Where, BC - biological efficiency,\%; A - number of pests in the experiment before spraying; a - number of pests in the experiment after spraying; $\mathrm{V}$ - number of pests in the control variant before spraying; and, $\mathrm{v}$ - number of days after spraying the pest under control.

The agro-technical and chemical (chemical) methods of rice pest control were carried out on the basis of the following experimental system.

Areas of not less than $100 \mathrm{~m} 2$ were set aside for small field experiments. Each variant of our study was conducted in four returns.

In conducting agrotoxicological research Sh.T. Khojaev [4]. The experiments were carried out on the basis of "Methods of conducting field experiments" developed by N.Sh. Nurmatov and others [3].

\section{Results and discussion}

Insects are systematically arthropods, tracheae, and insects, as well as crustaceans. The use of modern harmonized intensive technology in agricultural crops around the world, including rice, creates favorable conditions for the development of various pests (pests, diseases and weeds), along with increasing productivity, resulting in the loss of much of the crop.

In our experiments, as a result of our targeted observations in 2020 at the experimental fields of the Rice Research Institute, samples of 10 species of pests and other arthropods suitable for rice were identified. On the surface of each of these pests is shown at what stage of plant development and to what extent.

Germination in the experimental fields of Iskandar rice, Leptestheria dahalacensis Sars, Apus concriformis Schaff, and Cephus pygmaeus and maize during the growing season, pests were identified the most.

Experimental field observations revealed that Bokovlav crabs (Leptestheria dahalacensis Sars) and shielded crabs (Apus concriformis Sh.) appeared as soon as the rice fields were flooded and multiplied in late May and early June after rice planting. The common denominator for a group of pests that interfere with the growth of rice is associated with irrigated rice crops, which live in the turbid surface layer of rice during the damage stage and infect young grasses from seed germination to the accumulation phase. These pests are as follows.

Rice long nose (Hydronomus sinuaticollis Faust.) Is a three-legged black beetle with a body length of 4-5 $\mathrm{mm}$. Whiskers and legs are yellowish-brown, the larvae (worms) do not have hind legs, 7-8 mm long. Both ends of the body are very narrow, the top is covered with small hairs, and completes the development period in one year. The larvae overwinter in the surface layer of the soil. In the spring they turn brown and then turn brown. Females lay eggs on the inside of the stems, and here the larvae that hatch from the eggs damage the grass. 
Coastal fly - mosquitoes (Diptera) family, Ephydridae family Ephydra macellaria Egger. It is found in almost all rice fields of Tashkent region. The length of the shoreline is 4.0-4.5 mm and is metallic green in color. The eggs are white, oval, and the larvae are pale yellow, $7 \mathrm{~mm}$ long. The larvae of the shore mosquito crawl to the bottom of the rice paddy and gnaw on the grass. In years when the pest is very abundant, fungi can also be found on young leaves. The shore mosquito produces three generations a year.

Barley minions - Diptera family, Ephydridae family Hydrellia griseola Fall. The fly is gray, with large eyes on the head. The body is covered with a dark shield. The legs are dark brown. The wings are large and shiny. The larva is egg-like, whitish-yellow; the body is divided into 13 joints. The head has developed (energetic) jaws. The size of the adult larva 3-3.8 $\mathrm{mm}$. This pest appears in rice in mid-June and lays eggs on top of the leaves. The larvae that hatch from the eggs penetrate the leaf and penetrate the parenchymal tissue or the stem of the young plant, thus drying the rice completely.

Tailed calf - It belongs to the family Orthoptera, family Gryllotalpidae (Gryllotalpa unisrina Saus.). The surface of this species of insect is covered with short brown hairs. The claws of the forelegs are widened, and the claws have 5 pairs of sharp-toothed growths adapted to dig the ground. Wing length is $12-18 \mathrm{~mm}$ and brown veins are visible. The mature calf digs a spot closer to the ground and eats the roots of the plants.

Rice locust - Orthoptera belongs to the family Acrididae, Exya fuscvoitata Marsch. It is found in weed-infested areas. The body is green with black stripes. His mustache and legs are reddish-brown. The larvae are green. It eats the leaves and the husk of the grain from the edge. They do not live in a herd. In the cracks of the ground lays eggs in the form of bumps on the rice stalks.

Juices - Homoptera family, Aphididae family, Shiraphis gramina Rond. is an insect belonging to the genus, and the aphids that fall on cereal plants cause great damage, mainly to grain crops. The body is green, 1.2-2 $\mathrm{mm}$ long. The length of his mustache is more than half of his body. The length of the suction tubes corresponds to one-sixth of the body. Syrups appear on rice in July. They form dense colonies mainly on leaves, stems and stems. They absorb the sap of the plant and slow down its growth and development, as a result of which the spikes do not germinate or the resulting grain becomes empty.

Research has shown that the following pests are present in rice agrobiocenosis in 2020: 62.0 pieces of leptestheria dahalacensis Sars. in $1 \mathrm{~m}^{2}$; two larvae of barley minor Hydrellia griseola 0.5 larvae of Fall; 48 larvae of shore mosquito Ephydra macellaria Egger. per $1 \mathrm{~m}^{2}$; 1 beetle Hydronomus sinuaticollis Faust. per $1 \mathrm{~m}^{2}$ of rice water, and lastly, 10 beetles per stalk of corn moth Ostrinia nubilalis $\mathrm{Hb}$. (Table 1).

These observations show that in the experimental areas, during the germination of rice, shield crabs, bokoplav crabs, and the end of the tuber period - the larvae of corn moth and the worms of grain stalks - are more common. 
Table1. The rate of encounter of pests in the experimental field (Tashkent region, Ortachirchik district, 2020).

\begin{tabular}{|c|c|c|c|}
\hline$\#$ & Scientific Name & $\begin{array}{l}\text { number in the } 1 \mathrm{~m}^{2} \\
\text { field, pes }\end{array}$ & $\begin{array}{l}\text { Number of pests } \\
\text { on } 1 \text { stem, pes }\end{array}$ \\
\hline 1 & Apus concriformis Schaff & 18 & - \\
\hline 2 & $\begin{array}{l}\text { Leptestheria dahalacensis } \\
\text { Sars }\end{array}$ & 62 & - \\
\hline 3 & Hydrellia griseola Fall & - & $2 / 0.5$ \\
\hline 4 & Ephydra macellaria Egger & - & 48 \\
\hline 5 & $\begin{array}{c}\text { Hydronomus sinuaticollis } \\
\text { Faust }\end{array}$ & 1 & - \\
\hline 6 & Ostrinia nubilalis $\mathrm{Hb}$ & - & 10 \\
\hline 7 & Gryllotalpa unispina Saus & 0.3 & - \\
\hline 8 & Exyafuscvoitata Marsch & 1 & - \\
\hline 9 & Shiraphisgramina Rond & - & 7 \\
\hline 10 & Cephus pygmaeus & - & 9 \\
\hline
\end{tabular}

Note: 2/0.5-two-stem barley minor larvae.

Bokoplav shrimp - Phyllopoda is a pest belonging to Leptestheria dahalacensis Sarsturi. Its body is covered with joints, elongated, shiny covering, and the side of the abdomen is exposed. The back of the body is divided into two. It has two loops on each part. Occurs at the same time as the shield shrimp in the rice paddy, i.e. after the water has been submerged, stirring the top layer of soil, making the water muddy, which cuts the roots of the grass, separates them from the ground, and destroys them.

Corn propeller - It is a pest belonging to the species Pyralidae family (Ostrinia nubilalis $\mathrm{Hb}$.). Mature worms are 17-18 $\mathrm{mm}$ long, yellowish-gray in color. The head is brown and the waist has a dark stripe. Mature worms overwinter on the stems of plants. The butterfly flies in May-June. It lays 120 to 1,200 eggs in layers on the stem. The young larvae that hatch from the eggs first live together. It then damages the rice seedlings next to it.

The presence of round holes and pathways into the stem at the end of the stem are the main signs of damage. The system of protection of rice crops from pests is a sensible combination of different methods, the basis of which is aimed at creating unfavorable conditions for the reproduction, spread and harmful activity of pests, and at the same time promotes good plant growth, maintaining beneficial activity of entomophagous.

In our research, the following modern pesticides were tested using pesticides during rice germination at different consumption rates.

1. Option -Nurell-D 55\% em.k (Cypermethrin + chlorpriphos) -1.5 1/ha.

2. Option -Tayshin 500 s.d.g (Clothianidin) $-0.06 \mathrm{~kg} / \mathrm{ha}$

3. Option -Atilla 5\% em.k (Lambda-cyhalotrin) -0.5 1/ha

4. Variant-andoza (Fufanon 57 em.k (Malation) 1,0 1/ha)

5. Option-control

The consumption standards of modern chemical means mentioned above were tested in 2019. As a result of the selections made in 2019, experiments were carried out in 2020 on chemicals with the best performance. In the experiment, a new generation of insecticides against pests that cause damage during the germination phase of rice was tested at different 
consumption rates (Figure 1). Processing was carried out using a motorized hand apparatus at the expense of 200 liters of water consumption per hectare. In the study, entomological controls were performed for 14 days before and after spraying. Prior to processing, the number of shrimp in all variants ranged from 61.3 to 64.6 per $1 \mathrm{~m}^{2}$, after which they gradually began to decrease (except for the control section). Accordingly, we can see that the biological efficiency has also increased. During the last calculation day (14) it was found that high, satisfactory results were obtained in almost all variants (92.8-93.9\%\%). In the experiment, Fufanon was used as a standard against bocoplav shrimp, 57\% em.k. (1.0 1/ha) in the applied variant, the biological efficiency was $89.9 \%$ on 14 days of treatment, Tayshin 500 s.d.g (Clothianidin) $-0.06 \mathrm{~kg} / \mathrm{ha}$ in 14 days, the biological efficiency of the drug was $92.8 \%$. In the experiment, Nurell D 55\% em.k. - in the variant treated with 1.5 $1 /$ ha, we can see that the biological efficiency of the chemical was the highest at 14 days, $93.9 \%$.

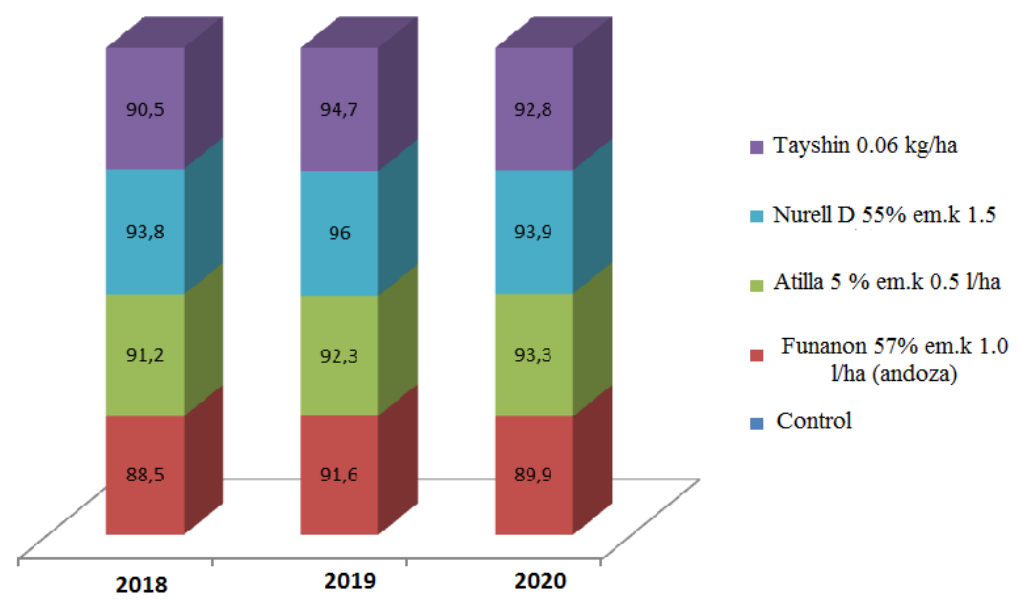

Fig. 1. Biological efficacy of chemicals used against bakoplav shrimp, \%.

Of the chemicals used against shield shrimp during rice germination, Fufanon $57 \%$ em.k. (1.0 1/ha) was used as a standard and its biological efficiency was $89.8 \%$ after 14 days, in the experiment with the newly tested Tayshin 500 s.d.g (Clothianidin) $-0.06 \mathrm{~kg} / \mathrm{ha}$ in 14 days - 91, 6\%, Atilla 5\% em.k (Lambda-cyhalotrin) -0.51/ha, biological efficiency 14 days $-90.4 \%$, Nurell-D 55\% em.k (Cypermethrin + chlorpriphos) -1 , The biological efficiency of the variant applied to 51 /ha was 14 days - 93.1\% (Table 2). According to the results of two years of experiments, Nurell D, which has achieved good biological efficiency, has a 55\% em.k. $1.5 \mathrm{l} / \mathrm{ha}$ and Tayshin 500 s.d.g. Production tests of $0.06 \mathrm{~kg} / \mathrm{ha}$ of chemical agents were carried out on the experimental area of the institute on 2.0 hectares. 
Table 2. Biological efficacy of chemicals used against Apus concriformis Schaff (Experimental area of Ortachirchik district, Tashkent region, 2020)

\begin{tabular}{|c|c|c|c|c|c|c|c|}
\hline \multirow{3}{*}{ \# } & \multirow{3}{*}{ Options } & \multirow{3}{*}{ 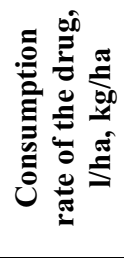 } & \multicolumn{4}{|c|}{$\begin{array}{c}\text { The average number of shielded } \\
\text { shrimp per } 1 \mathrm{~m}^{2}\end{array}$} & \multirow{3}{*}{ 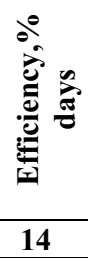 } \\
\hline & & & \multirow{2}{*}{$\begin{array}{c}\text { Until } \\
\text { processing }\end{array}$} & \multicolumn{3}{|c|}{$\begin{array}{c}\text { In the days after } \\
\text { processing }\end{array}$} & \\
\hline & & & & 3 & 7 & 14 & \\
\hline 1 & Nurell-D, 55\% em.k. & 1.5 & 15.3 & 6.0 & 3.0 & 1.7 & 93.1 \\
\hline 2 & Tayshin 500 s.d.g & 0.06 & 14.7 & 6.0 & 3.0 & 2.0 & 91.6 \\
\hline 3 & Atilla $5 \%$ em.k. & 0.5 & 16.7 & 6.3 & 4.0 & 2.6 & 90.4 \\
\hline 4 & $\begin{array}{c}\text { Fufanon, } 57 \% \text { em.k. } \\
\text { (default) }\end{array}$ & 1.0 & 20.0 & 8.3 & 5.6 & 3.3 & 89.8 \\
\hline 5 & Control (unprocessed) & - & 16.7 & 18.3 & 22.0 & 27.0 & \\
\hline
\end{tabular}

In the production test, Nurell D against pests was found to be $55 \%$ em.k. In the treated variant at $1.5 \mathrm{l} / \mathrm{ha}$, the biological efficiency was $91.8 \%$ for 14 days, with Tayshin 500 s.d.g. In the chemically applied variant of $0.06 \mathrm{~kg} / \mathrm{ha}$, the biological efficiency was $91.2 \%$.

In the study, Tayshin 500 s.d.g (Clothianidin) $-0.06 \mathrm{~kg} / \mathrm{ha}$ and Nurell-D 55\% em.k (Cypermethrin + chlorpriphos) $-1.5 \mathrm{l} / \mathrm{ha}$ were used against pests that cause significant damage during the germination phase of rice. the use of chemicals has been found to be a cost-effective crop.

Several factors affect the yield of rice, not one. High yields of all crops, including rice, also depend on successful pest control. In the experiments, at the end of the season, samples were taken according to the methods, the crop was harvested, biometric analyzes were performed, and yields were determined.

According to the results of a 3-year study, the non-pest control option in the rice field was 51.0 ts in $2018,53.6$ ts in 2019 , and 60.6 ts in 2020. was obtained. In the study, Fufanon was used as a benchmark in the 1.0 -liter variant of pesticides applied at $57 \%$ em.c. centner high yield was obtained.

In the study, the average yield of rice in the Iskandar variety using pesticides (Nurell D $55 \%$ em.k. $1.5 \mathrm{l} / \mathrm{ha}$ ) was $71.1 \mathrm{q}$ in $2018,70.2 \mathrm{q}$ in 2019 , and 73 in 2020 ., 8 quintals were harvested. It can be seen that due to the high pest efficiency of this chemical, an additional yield of $13.2 \mathrm{q} /$ ha was achieved in 2020 compared to the control. In scientific studies, Tayshin found 500 s.d.g. $(0.06 \mathrm{~kg} / \mathrm{ha})$ with the use of chemical means in 2020 it was possible to get $70.7 \mathrm{q} / \mathrm{ha}$ and an additional yield of $10.1 \mathrm{q} / \mathrm{ha}$.

In two years of research, which gave good results (Nurell D 55\% em.k. 1.5 1/ha), Tayshin 500 s.d.g. $(0.06 \mathrm{~kg} / \mathrm{ha})$ were tested for the production of chemical agents on the experimental area of 2.0 hectares of the institute. In the variant used in the production test (Nurell D 55\% em.k. 1.5 1/ha), 70.2 q, Tayshin 500 s.d.g. $(0.06 \mathrm{~kg} / \mathrm{ha})$ yielded 68.5 quintals in the variant in which the chemical agent was used.

\section{Conclusions}

In conclusion, it can be said that due to timely protection from pests that damage the growth and development of plants in the rice biocenosis, the yield is maintained from 7.8 to 13.2 
quintals per hectare. According to the results of scientific research, the following conclusions were reached:

In the rice agrobiocenosis, 10 species of pests that damage the rice plant during the season were identified. According to rice grasses, Leptestheria dahalacensis Sars, Apus concriformis Sh., Ostrinia nubilalis $\mathrm{Hb}$, corn stalk and Cephus pygmaeus were found to damage the stems and leaves. A growth calendar has been developed. In the pest experiment during the rice germination period, Nurell D was found to contain $55 \%$ em.k. (Cypermethrin + chlorpriphos) - in the variant applied to $1.5 \mathrm{l} / \mathrm{ha}$, the biological effectiveness of the drug is the highest for 14 days - $93.9 \%$, in the variant treated with Tayshin 500 s.d.g (Clothianidin) $-0.06 \mathrm{~kg} /$ ha for 14 days $-93.3 \%$.

In the experiment, Nurell D 55\% em.k (1.5 1/ha) yielded 73.8 quintals of Iskandar variety, which is 13.2 quintals/ha more than the control. Tayshin 500 s.d.g. $(0.06 \mathrm{~kg} / \mathrm{ha})$ yielded 70.7 ts/ha in the variant in which the chemical agent was used, and an additional yield of 10.1. According to the study, in the biocenosis of rice, due to timely protection from pests that damage the growth and development of the plant, it is possible to save from 7.8 to 13.2 quintals per hectare.

\section{References}

1. N. Teshaev, B. Mamadaliyev, A. Ibragimov, S. Khasanov, InterCarto. InterGIS, 26(3), 324-333 (2020)

2. A. I. Kasyanov, Rice pests, 220 (2008)

3. A. Jumanov, S. Khasanov, A. Tabayev, G. Goziev, U. Uzbekov, E. Malikov, In IOP Conference Series: Earth and Environmental Science, 614(1), 012150 (2020)

4. SH. T. Khujaev, Guidelines for testing insecticides, acaricides, biologically active substances and fungicides, 110 (2004)

5. A. A. Shokirov, A. A. Kodyakov, Methodical manual on detection of pests of rice in Uzbekistan and measures to combat its pests and diseases, 14 (1987)

6. R. Kulmatov, A. Taylakov, S. Khasanov, Environmental Science and Pollution Research, 28(10), 12245-12255 (2021)

7. M. W. Akhtar, D. Sengupta, A. Chowdhury, Interdiscip. Toxicol., 2, 1-12 (2020)

8. M. Z. Alam, Intl. J. Appl. Res. Stud., 2, 1-16 (2013)

9. I. Aslanov, S. Khasanov, Y. Khudaybergenov, M. Groll, Ch. Opp, F. Li, E. Ramirez Del-Valle, In E3S Web of Conferences, 227, 02005 (2021)

10. M. N. Bari, N. Ahmed, S. Haque, M. Rabbi, M. K. Iftekharuddaula, Bangladesh Rice J. 19, 17-31 (2015)

11. S. Isaev, S. Khasanov, Y. Ashirov, T. Karabaeva, A. Gofirov, In E3S Web of Conferences, 244, 02012 (2021)

12. M. Bux, M. H. Khan, N. Ahmad, M. Tofique, M. Ismail, Pak. J. Agri., 29, 137-145 (2013)

13. S. Isaev, S. Khasanov, Y. Ashirov, A. Gofirov, T. Karabaeva, In E3S Web of Conferences, 244, 02047 (2021)

14. K. L. Heong, J. Rice Today, 38 (2014)

15. R. A. Kulmatov, S. A. Adilov, S. Khasanov, In IOP Conference Series: Earth and Environmental Science, 614(1), 012149 (2020)

16. K. L. Heong, Planthoppers: new threats to the sustainability of intensive rice production systems in Asia, 221-232 (2009) 
17. S. Isaev, I. Begmatov, G. Goziev, S. Khasanov, In IOP Conference Series: Materials Science and Engineering, 883(1), 012080 (2020)

18. Y. Peng, F. Li, N. Xu, R. Kulmatov, K. Gao, G. Wang, Y. Zhang, Y. Qiao, Y. Li, H. Yang, S. Hao, Q. Li, S. Khasanov, Chinese Journal of Eco-Agriculture, 29(2), 312-324 (2021)

19. W. L. Zhang, J. Agr. Food Chem., 65, 1093-1101 (2017)

20. X. Q. Wang, Pest Manag. Sci., 73(6), 1277-1286 (2017) 